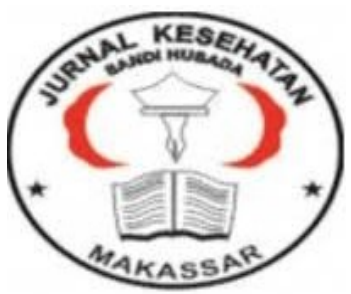

Jurnal Ilmiah Kesehatan Sandi Husada

hhttps://akper-sandikarsa.e-journal.id/JIKSH

Vol 11, No, 1, Juni 2020, pp;353-357

p-ISSN: 2354-6093 dan e-ISSN: 2654-4563

DOI: $10.35816 /$ jiskh.v10i2.293

\title{
Hubungan Rhinitis Alergi dengan Kejadian Asma Bronkial
}

LITERATUR REVIEW

Relation of Allergic Rhinitis with the Occurrence of Bronchial Asthma

\section{Hadriyan Akbar Arief}

Pendidikan Dokter, Fakultas Kedokteran Universitas Lampung

\section{Artikel info}

\section{Artikel history:}

Received;15 April 2020

Revised;18 April 2020

Accepted; 30 April 2020

\begin{abstract}
Abstrak.
Rhinitis alergi merupakan radang mukosa nasal yang dipicu oleh paparan alergen. Rhinitis alergi memiliki keterkaitan dengan asma bronkial. Untuk itu, hubungan rhinitis alergi dengan kejadian asma bronkial perlu diketahui dalam menunjang pendekatan diagnosis dan pengobatan satu sama lain. Pada artikel ini dilakukan studi berbagai literatur dengan upaya meringkas dan membandingkan hasil pemahaman terkini sehingga terbentuk publikasi yang relevan. Hubungan keduanya dijelaskan secara patofisiologis dan epidemiologis. Secara patofisiologis mencakup efek fisiologi hidung terhadap bronkus, reflek nasobronkial, inflamasi serupa, serta mediator dan marker yang terlibat. Secara epidemiologis dijelaskan bahwa rhinitis merupakan faktor risiko signifikan timbulnya asma yang ber-onset saat dewasa.
\end{abstract}

\begin{abstract}
.
Allergic rhinitis defined as an inflammation on nasal mucosa which triggered by contact with allergen. Allergic rhinitis has been linked with bronchial asthma. For that reason, the relationship of allergic rhinitis with the incidence of bronchial asthma needs to be known in supporting the approach to diagnosis and treatment of one another. In this article a variety of literature studies are carried out to summarize and compare the results of the current understanding so that relevant publications are formed. The relationship between the two is explained pathophysiologically and epidemiologically. Pathophysiologically includes the effects of nasal physiology on the bronchus, nasobronchial reflexes, similar inflammation, and the mediators and markers involved. Epidemiologically, it is explained that rhinitis is a significant risk factor for the onset of asthma as an adult.
\end{abstract}




\author{
Keywords: \\ Allergic rhinitis; \\ Bronchial asthma; \\ Pathophysiologic; \\ Epidemiologic;
}

Coresponden author:

Email: hadriyan.27@gmail.com

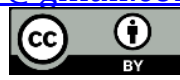

artikel dengan akses terbuka dibawah lisensi CC BY -4.0

\section{Pendahuluan}

Rhinitis didefinisikan sebagai radang mukosa nasal yang disebabkan oleh proses inflamasi. Rhinitis memiliki setidaknya satu dari gejala berikut: hidung tersumbat, rinore, bersin, dan gatal pada hidung. Gejala lain yang dilaporkan meliputi sakit kepala, sakit wajah, sakit telinga, gatal pada tenggorokan dan langit-langit mulut, mendengkur, dan terganggunya tidur. Rhinitis alergi dapat ditegakkan bila munculnya gejala-gejala tersebut dipicu oleh riwayat paparan alergen. Rhinitis alergi perenial (muncul sepanjang tahun) paling sering dikaitkan dengan tungau debu, spora jamur, dan bulu binatang, sedangkan rhinitis alergi musiman (muncul beberapa kali dalam setahun) dikaitkan dengan paparan alergen berupa serbuk sari yang bervariasi bentuknya, tergantung wilayah geografis. Rhinitis alergi sendiri secara patofisiologi dimediasi oleh reaksi hipersensitivitas tipe 1 (Tran dkk., 2011).

Rhinitis alergi merupakan masalah kesehatan global yang dapat memicu penyakit yang lebih parah lagi, salah satunya adalah asma. Sebagian besar pasien dari seluruh negara, kelompok etnis, dan usia menderita rhinitis alergi, dan tentunya kondisi ini dapat mempengaruhi kehidupan sosial, pola tidur, performa di sekolah maupun pekerjaan mereka. Rhinitis alergi dan asma merupakan kondisi inflamasi sistemik sehingga berisiko menimbulkan komorbiditas (Brozek dkk., 2017). Mukosa hidung dan mukosa bronkial memiliki gambaran yang serupa. Selain itu hidung dan bronkus memiliki fungsi yang sama yaitu sebagai saluran napas, dan dengan ini penting untuk diterapkan konsep "one airway one disease" (satu saluran, satu penyakit) (Caimmi dkk., 2012). Klinisi harus mampu mempertimbangkan kelainan di bagian lain saat satu bagian saluran udara terdiagnosis mengalami kelainan. Interaksi antara saluran udara atas dan bawah sudah dikenal dan dipelajari secara ekstensif sejak tahun 1990 (Bousquet dkk., 2008).

Studi epidemiologik menunjukkan kalau asma dan rhinitis seringkali diderita oleh pasien yang sama. Terdapat lebih dari $80 \%$ penderita asma mengalami rhinitis dan $10-40 \%$ pasien dengan rhinitis menderita asma. Prevalensi asma pada subjek tanpa rhinitis seringkali $<2 \%$. Selain itu, di AS sendiri terdapat sekitar 56 juta orang atau $20 \%$ penduduk menderita rhinitis alergi dan 5\% nya menderita asma. Tidak hanya di AS, penelitian epidemiologi menyatakan kalau prevalensi rhinitis alergi dan asma meningkat di seluruh dunia (Harsono dkk., 2013). Adanya rhinitis alergi biasanya dapat memperburuk kejadian asma, meningkatkan risiko serangan asma, dan lebih butuh melakukan kunjungan darurat maupun rawat inap terkait asmanya (Brozek dkk., 2017).

Asma juga merupakan masalah kesehatan mayor di dunia dan dinilai berbahaya serta merugikan. Menurut data WHO (World Health Organization), sebanyak 15 juta jiwa mengalami disability-adjusted life years (DALYs) per tahunnya yang disebabkan asma, mewakili 1\% dari total beban penyakit global (Global Initiative for Asthma, 2010). Unit Epidemiologi dan Statistik Asosiasi Paru Amerika mengatakan bahwa di Amerika, lebih dari 34 juta orang dewasa menderita asma, dan Centers for Disease Control Surveillance untuk asma menyatakan prevalensi asma meningkat 75\% dari 1980-1994, dan WHO 
memperkirakan bahwa jumlah orang yang mengalami asma akan berkembang lebih dari 100 juta pada tahun 2025. Tiap tahun, hal ini menyebabkan lebih dari 10 juta waktu produktif hilang, hampir 2 juta kunjungan ruang gawat darurat berkaitan dengan asma, \$14.7 milyar untuk biaya tenaga kesehatan dan \$5 juta untuk biaya tidak langsung, dan lebih dari 33.000 kematian berkaitan dengan asma (Lorensia dkk., 2013). Asma bronkial termasuk ke dalam sepuluh besar penyebab kesakitan (morbiditas) dan kematian (mortalitas) di Indonesia. Pernyataan tersebut didukung oleh data studi Survei Kesehatan Rumah Tangga (SKRT) di berbagai propinsi di Indonesia. Survei kesehatan rumah tangga tahun 1986 menyatakan bahwa asma bronkial menduduki urutan ke-5 dari 10 penyebab kesakitan, bersama dengan bronkitis kronik dan emfisema. Pada SKRT 1992, asma bronkial, bronkitis kronik dan emfisema dinyatakan sebagai penyebab kematian ke-4 di Indonesia atau sebesar 5,6\%. Tahun 1995, prevalensi asma bronkial diseluruh Indonesia sudah mencapai 13/1000, dibandingkan dengan bronkitis kronik 11/1000 dan obstruksi paru 2/1000 (Irawan, 2012).

\section{Metode}

Metode penelitian yang digunakan adalah studi literatur dari berbagai jurnal nasional dan internasional. Metode ini berupaya untuk meringkas kondisi pemahaman terkini tentang suatu topik. Studi literatur mengulas materi yang telah disajikan sebelumnya dan meringkas materi menjadi publikasi relevan, kemudian membandingkan hasil yang disajikan dalam artikel.

\section{Hasil Dan Pembahasan}

Untuk mengetahui hubungan rhinitis alergi dengan kejadian asma bronkial, konsep paling penting yang perlu diketahui adalah integrasi hidung-paru, dimana memiliki kesamaan anatomi dan fungsi. Peran hidung meliputi penghangatan udara, humidifikasi udara, penyaringan partikel/gas, dan pembersihan mukosiliar sehingga pada akhirnya mempengaruhi kondisi udara pada saluran pernapasan bagian bawah. Selain proses peradangan, fungsi protektif dari hidung yang menurun akan ikut mengganggu fungsi saluran pernapasan bagian bawah dan dari sini dapat dijelaskan beberapa hubungan antara rhinitis dan asma (Brozek dkk., 2017).

Terganggunya pengaturan udara oleh mukosa hidung dapat mempengaruhi peran saluran pernapasan bagian bawah. Pasien yang menderita penyakit hidung kronis dibuktikan mengalami penurunan fungsi pembersihan mukosiliar, tetapi efeknya terhadap saluran pernapasan bawah masih belum jelas. Sedangkan saluran hidung pada penderita asma mengalami penurunan kemampuan untuk menghangatkan dan melembabkan (humidifikasi) udara pasca inspirasi (Brozek dkk., 2017).

Terganggunya penghangatan dan pelembaban udara oleh hidung memiliki beberapa efek penting. Respon hidung yang lebih kuat terhadap udara dingin ditemukan pada pasien dengan rhinitis dan asma, jika dibandingkan dengan mereka yang rhinitis saja. Pada pasien asma, tetapi tidak dalam kondisi sehat, provokasi oleh udara dingin di hidung menyebabkan bronkokonstriksi sementara udara hangat menyebabkan bronkodilatasi. Hal tersebut terjadi karena adanya reflek nasobronkial (Cingi dkk., 2015). Peningkatan transfer panas dan air di saluran pernapasan bagian bawah dapat mengubah fungsi bronkial dan hidung secara berhubungan. Nantinya hidung akan menambah aktivitas pertukaran panas sehingga diameter saluran hidung berkurang, tetapi mekanisme tersebut tidak mempengaruhi kerja saluran pernapasan intratorakal. Ditemukan pula 
pernyataan lain bahwa rhinitis persisten memicu terjadinya hipereaktivitas non spesifik oleh bronkus (Harsono dkk., 2013).

Rhinitis alergi dan asma merupakan penyakit radang dengan etiologi yang serupa. Selain itu, keduanya juga memiliki mekanisme inflamasi serupa yang dimediasi oleh berbagai jenis sel. Beberapa mediator seperti IgE yang diproduksi secara lokal dan sistemik serta keterlibatan sumsum tulang secara sistemik, keduanya memiliki hubungan. Konsep tersebut juga didukung oleh penelitian yang melibatkan provokasi menggunakan alergen: infiltrasi inflamasi yang diinduksi alergen dan mobilitas mediator menunjukkan tidak adanya perbedaan, baik antara cairan hidung dan bronkial maupun mukosa hidung dan bronkial. Peric dkk. menemukan peningkatan eosinofil epitelium 24 jam yang signifikan di dalam hidung dan bronkus setelah hidung diprovokasi alergen pada penderita rhinitis alergi musiman tanpa asma, yang berkaitan langsung dengan ekspresi molekul adhesi (Peric dkk., 2011). Eosinofil darah dan interleukin-5 (IL-5) juga mengalami peningkatan. Sebaliknya, saat segmen bronkus diprovokasi oleh alergen pada penderita rhinitis alergi tanpa asma, hasilnya terdapat respon inflamasi oleh hidung. Respon cepat maupun lambat keduanya juga tampak serupa (Tsilochristou dkk., 2013).

Anak-anak penderita rhinitis alergi tanpa asma seringkali mengalami hiper-responsif bronkial (BHR) terhadap metakolin, adenosin, atau histamin, terutama saat atau setelah musim alergi. Terdapat penelitian yang mengevaluasi prevalensi BHR pada anak penderita rhinitis alergi lewat provokasi bronkus dengan metakolin: hasilnya anak tanpa asma menunjukkan prevalensi yang tinggi, dan secara signifikan dapat dikaitkan dengan kejadian rhinitis alergi persisten. Systematic review terbaru melaporkan pengaruh rhinitis alergi terhadap nilai nitric oxide diekshalasi (eNO) yang merupakan marker non-invasif bila terjadi inflamasi di saluran pernapasan bagian bawah. Hasilnya marker tersebut tampak meningkat pada anak yang menderita rhinitis alergi dibandingkan mereka yang tidak menderita rhinitis alergi, tanpa rhinitis, maupun anak dengan riwayat atopik. Pernyataan tersebut menunjukkan bahwa saat hidung mengalami peradangan, saluran pernapasan bagian bawah ikut memberikan penanda (Tsilochristou dkk., 2013).

Secara umum, perkembangan penyakit asma lebih banyak terjadi pada pasien dengan rhinitis dibandingkan mereka yang tidak mengalami rhinitis. The Children's Respiratory Study menunjukkan bahwa rhinitis alergi pada masa bayi secara independen berisiko dua kali lebih besar berkembang menjadi asma saat pasien berusia 11 tahun. Pada anak-anak dan dewasa, dilakukan penelitian secara follow-up selama 23 tahun pada mahasiswa. Secara signifikan sebanyak $10,5 \%$ dari para mahasiswa yang awalnya didiagnosis dengan rhinitis alergi, penyakitnya berkembang menjadi asma, dibandingkan dengan 3,6\% mereka yang tidak menderita rhinitis. Penelitian ini dikonfirmasi oleh penelitian lain. Dalam dua studi, onset asma dapat dikaitkan dengan rhinitis alergi, dan penelitian yang dilakukan di AS menunjukkan bahwa rhinitis meningkatkan risiko perkembangan asma sekitar tiga kali lipat, baik pada pasien atopik maupun nonatopik. Pasien rhinitis dengan gejala hidung yang parah serta memiliki riwayat sinusitis memiliki peningkatan risiko perkembangan asma yang lebih besar lagi. Penulis menyimpulkan bahwa rhinitis merupakan faktor risiko signifikan timbulnya asma yang ber-onset saat dewasa, baik pada subyek atopik maupun nonatopik (Brozek dkk., 2017).

Saat diagnosis rhinitis alergi dan asma berhasil ditegakkan, terdapat pendekatan yang perlu diperhatikan dalam melakukan pengobatan, yaitu: a) Antihistamin-H1 oral tidak dianjurkan, tetapi bukan pula kontraindikasi dalam pengobatan asma. b) Glukokortikosteroid intranasal dinilai efektif mengobati asma. c) Glukokortikosteroid intranasal mungkin efektif mengurangi risiko eksaserbasi asma dan perlunya rawat inap. d) Peran glukokortikosteroid intrabronkial dalam rhinitis tidak diketahui. e) Montelukast 
efektif dalam pengobatan rhinitis alergi dan asma pada pasien usia di atas 6 tahun. f) Imunoterapi subkutan direkomendasikan untuk rhinitis dan asma pada orang dewasa, tetapi dibatasi oleh efek samping, khususnya pada penderita asma. g) Antibodi monoklonal anti-IgE efektif untuk rhinitis dan asma (Lohia dkk., 2013).

\section{Simpulan Dan Saran}

Rhinitis alergi didefinisikan sebagai radang mukosa nasal yang disebabkan oleh proses inflamasi, dan dipicu oleh riwayat paparan alergen. Rhinitis alergi merupakan masalah kesehatan global yang dapat memicu asma bronkial. Hubungan keduanya dijelaskan secara patofisiologis melalui efek fisiologi hidung terhadap bronkus, mekanisme reflek nasobronkial, mekanisme hipereaktivitas non spesifik oleh bronkus, mekanisme inflamasi yang serupa, serta mediator dan marker apa saja yang terlibat. Secara epidemiologis diketahui bahwa rhinitis merupakan faktor risiko signifikan timbulnya asma yang beronset saat dewasa, baik pada subyek atopik maupun nonatopik. Selain itu, terdapat beberapa pendekatan pengobatan yang perlu diperhatikan dalam mengobati kedua penyakit ini.

\section{Daftar Rujukan}

Bousquet, J., Khaltaev, N., Cruz, A. A., Denburg, J., Fokkens, W. J., Togias, A., ... \& Agache, I. (2008). Allergic rhinitis and its impact on asthma (ARIA) 2008. Allergy, 63, 8160.

Brożek, J. L., Bousquet, J., Agache, I., Agarwal, A., Bachert, C., Bosnic-Anticevich, S., ... \& de Sousa, J. C. (2017). Allergic Rhinitis and its Impact on Asthma (ARIA) guidelines-2016 revision. Journal of Allergy and Clinical Immunology, 140(4), 950-958.

Caimmi, D., Marseglia, A., Pieri, G., Benzo, S., Bosa, L., \& Caimmi, S. (2012). Nose and lungs: one way, one disease. Italian journal of pediatrics, 38(1), 60.

Cingi, C., Muluk, N. B., Cobanoglu, B., Çatli, T., \& Dikici, O. (2015). Nasobronchial interaction. World Journal of Clinical Cases: WJCC, 3(6), 499.

Irawan, Y. (2012). Perbedaan Faktor Risiko Terjadinya Asma Bronkial Pada Pasien Dengan Asma Bronkial Dan Pasien Tanpa Asma Bronkial Di Poli Anak Rawat Jalan RSUD Dr. H. Abdul moeloek Lampung Pada Oktober-Desember 2011. Jurnal Majority, $1(1)$.

Lohia, S., Schlosser, R. J., \& Soler, Z. M. (2013). Impact of intranasal corticosteroids on asthma outcomes in allergic rhinitis: a meta-analysis. Allergy, 68(5), 569-579.

Lorensia, A., Wijaya, R. I., \& Canggih, B. (2013). Studi Efektifitas Biaya terkait Pemilihan Obat Asma Bronkiale Rawat Inap di Suatu Rumah Sakit Swasta di Surabaya. Jurnal Ilmiah Sains \& Teknologi, 7(1), 56-63.

Perić, A., Vojvodić, D., Vukomanović-Đurđević, B., \& Baletić, N. (2011). Eosinophilic inflammation in allergic rhinitis and nasal polyposis. Archives of Industrial Hygiene and Toxicology, 62(4), 341-348.

Tran, N. P., Vickery, J., \& Blaiss, M. S. (2011). Management of rhinitis: allergic and nonallergic. Allergy, asthma \& immunology research, 3(3), 148-156.

Tsilochristou, O. A., Douladiris, N., Makris, M., \& Papadopoulos, N. G. (2013). Pediatric allergic rhinitis and asthma: can the march be halted?. Pediatric Drugs, 15(6), 431-440. 